\title{
Morphological Characteristics of Smooth Muscle Cells Isolated from the Rat Ductus Deferens
}

\author{
NIE Hong ${ }^{1, *}$, YIN Zhen $^{1}$, LIN Qian-xuan ${ }^{2}$, FENG Xue-ying ${ }^{2}$, ZHANG Jian-yu ${ }^{1}$, LI Kong-yan ${ }^{1}$ \\ (1. Jinan University College of Pharmacy, Guangzhou Guangdong 510632, China; \\ 2. Jinan University International School, Guangzhou Guangdong 510632, China)
}

\begin{abstract}
The aim of this study was to establish a method of isolating and culturing smooth muscle cells from the ductus deferens of rats. Smooth muscle cells were prepared from ductus deferens by explanting technique after dissection of adventitia and intimae, and cultured in vitro. The identification of the smooth muscle cells were verified by using anti $\alpha$-smooth muscle actin ( $\alpha$-SMA) immunohistochemistry studies. The result suggested that the cells are multi-morphous, showing long fusiform or star shapes. The apophysis of cells contacted and coalesced to each other, in some regions the cells overlapped in multilayer, while in the other regions they formed monolayer that fluctuated and showed a "peak-valley" shape. They presented a positive reaction through immunohistochemistry studies. The purity of the cells was more than $99 \%$ through this method. The culturing of smooth muscle cells by explanting technique is simple and stable.
\end{abstract}

Key words: Ductus deferens smooth muscle cells; Cell culture; Rat

\section{大鼠输精管平滑肌细胞的体外培养及形态学特征 \\ 聂 红 ${ }^{1, *}$, 尹 震 ${ }^{1}$, 林倩旋 $^{2}$, 冯雪堂 ${ }^{2}$, 张建宇 $^{1}$, 李孔燕 ${ }^{1}$ \\ (1. 暨南大学 药学院, 广东 广州 510632; 2. 暨南大学 国际学院, 广东 广州 510632)}

摘要: 建立大鼠输精管平滑肌细胞的培养方法。取大鼠输精管, 剥离外膜和内膜, 用组织块法进行体外培养。 用抗 $\alpha$-SMA（anti $\alpha$-smooth muscle actin）免疫组化染色的方法鉴定培养的细胞。结果显示，在倒置显微镜下观察 细胞形态多样, 表现为长梭形或星形, 细胞伸出突起互相接触, 彼此融合, 部分区域细胞多层重叠, 部分区域细 胞单层高低起伏, 呈“峰一谷”状生长。免疫组化染色鉴定呈阳性反应, 用该方法所分离、培养的输精管平滑肌细 胞纯度达 $99 \%$ 以上。应用组织块法培养大鼠输精管平滑肌细胞, 操作简单, 结果稳定。

关键词: 输精管平滑肌细胞; 细胞培养; 大鼠

中图分类号：Q959.848 文献标识码：A 文章编号：0254-5853-(2008)06-0633-04

Algesia is one of the most common symptoms in clinics. At present, the therapeutic efficacy of chronic algesia is not ideal, and the usage of analgesics has been limited due to its serious adverse reactions. Thus widespread development in the investigation of analgesics is required. The Traditional Chinese Medicines (TCMs) may have the potential efficacy of analgesia, detumescence. Many of them were regarded as effective in the treatment of headaches, toothaches and trigeminal neuralgia.

It is difficult to study the active components from the TCMs (Huang et al, 2004). However, cell membrane chromatography has high application value, according to its high-flux, high efficiency and low financial cost (Li \& He, 2007; Yu et al, 2007). It indicated that opioid drugs can affect the opioid receptor to produce an analgesic

Received date: 2008-07-08; Accepted date: 2008-10-28

Foundation items: Supported by the Chinese National Natural Science Foundation (30400596); The Jinan University Natural Science Foundation

(51204017); The Science and Technology Innovation Project for Undergraduates of Jinan University (CX07080)

${ }^{*}$ Correspondence author（通讯作者）: NIE Hong, professor, Tel: +86 208522 2810; fax: +86 20 8522 4766; E-mail: tnieh@jnu.edu.cn

收稿日期：2008-07-08; 接受日期：2008-10-28 
effect. The opioid receptor has at least 8 kinds of sub-types, of which the rat ductus deferens is considered to contain the $\varepsilon$ receptor ( $\mathrm{Xu}$ et al, 2002). In the paper, smooth muscle cells were isolated and cultured from the ductus deferens of rats, which may be used in the study of analgesic in TCMs.

\section{Materials and methods}

\subsection{Animals}

Adult male SD rats, body weight approximately 300 g, purchased from Guangdong Province Medical Science Experimental Animal Center (SCXK, Guangdong, 2003-0002, Guangdong Province Animal Detection Centre, Proof No. 2007A003).

\subsection{Reagents}

PBS buffer (pH7.4); Trypsinase was purchased from AMRESCO. DMEM was purchased from Gibco. Fetal bovine serum was purchased from HyClone. Penicillin and streptomycin were purchased from Genom. $\alpha$-SMA, SABC kit (SA1021), DAB kit (AR1022) were purchased from Boster, China.

\subsection{Primary culture of tissue pieces}

A rat was injected with an intraperitoneal injection of $30 \mathrm{mg} / \mathrm{kg}$ pentobarbital sodium and depilation was performed in the operating field. After alcohol disinfection, a 3-4 cm transverse incision on the hypogastrium was made to isolate the two ductus deferens. They were disassociated and placed in asepsis PBS (containing $100 \mathrm{U} / \mathrm{mL}$ penicillin and $100 \mathrm{U} / \mathrm{mL}$ streptomycin), and rinsed 3 times every 2 mins to remove debris. The tunica adventitia ductus deferens was removed with micro-forceps under an anatomical microscope. The lumens was split with micro-scissors to peel off the endodermis and then the smooth muscle tissue was put into the asepsis PBS (containing $100 \mathrm{U} / \mathrm{mL}$ penicillin and $100 \mathrm{U} / \mathrm{mL}$ streptomycin) and rinsed 3 times every 2 mins. The tissue was cut into small masses of 1 $\mathrm{mm}^{3}$ with micro-scissors. The tissue masses were adhered uniformly to the bottom of the culture flask every $0.5 \mathrm{~cm}$ with a cyrto-mouth dropper. Then it was left to lie in the incubator for $1 \mathrm{hr}$ after resupination. Culture fluid (DMEM) was added into the flask and turned it over slowly. Finally, they were cultured in the incubator at $37^{\circ} \mathrm{C}$, which contained $95 \%$ air and $5 \% \mathrm{CO}_{2}$. The cell shape and its growing condition were observed every day. The culture fluid, which contained $20 \%$ fetal bovine serum, was changed every $2-3$ days.

\subsection{Serial subcultivation}

Passage: After cultivation for 18-25 days, the primary cells grew intensely to form flakiness on the bottom with the cells overlapping and aggregating with each other. For the amplification, the primary cells were collected when the cells covered about $80 \%$ of the bottom of the flask.

The cell culture fluid was poured away and the cells were washed with PBS twice under $37^{\circ} \mathrm{C}$, then $0.02 \%$ EDTA was used to wash them again. The cell dissociation buffer was added, which contained $0.2 \%$ trypsin and stood for 1-3 mins. Cell dissociation and detachment was observed under a microscope. Then DMEM containing $10 \%$ fetal bovine serum was added to the flask to terminate the digestion. The cell suspension was transferred to a $15 \mathrm{~mL}$ centrifuge tube and centrifuged at $1000 \mathrm{r} / \mathrm{min}$ for $5 \mathrm{mins}$ and the supernatant was thrown away. Then $2 \mathrm{~mL}$ of culture fluid was added to the flask. Finally, the dropper was used to blow the cells to produce cell suspension. One drop of suspension was added to the blood cell counting chamber to calculate the number of cells under a microscope. By the density of $1 \times 10^{5} / \mathrm{mL}$, the culture fluid was added to 25 $\mathrm{cm}^{2}$ culture flask, and incubated under $37^{\circ} \mathrm{C}$ with $95 \%$ air and $5 \% \mathrm{CO}_{2}$. Cell shape and its growing condition were observed every day and the culture fluid containing $10 \%$ fetal bovine serums was changed every $2-3$ days.

\subsection{Drawing of growth curve of smooth muscle cells}

The cells were collected when they were in an exponential phase of growth, and the cell culture fluid was poured away and the cells were washed with PBS twice at $37^{\circ} \mathrm{C}$, then washed again with $0.02 \%$ EDTA. The cell dissociation buffer, which contained $0.2 \%$ trypsin, was added and stood for 1-3 mins. The cell dissociation and detachment conditions were observed under a microscope. DMEM containing 10\% fetal bovine serum was added to terminate the digestion. To ensure the cells distributed uniformly, the flask was blown on. The cells were inoculated on a 24-pores cell culture plate with a density of $1 \times 10^{4} / \mathrm{mL}$. Three pores of cells were taken out to calculate the cell amount after 1, 3, 5, 7, 9, 11 days and the culture fluid was changed every 3 days. The average cell amount in each period was calculated and a growth curve drawn.

\subsection{Identification with immunohistochemistry staining}

Anti $\alpha$-smooth muscle actin( $\alpha$-SMA) immunohisto- 
chemistry staining was used to identify the smooth muscle cells in 3 or 4 generations.

A sterile glass cover was coated with polylysine and placed into a 6-pore-plate and cell suspension was added to cultivate the plates. The glass cover was taken off and fixed with $4 \%$ paraform for 90 mins. Then $3 \% \mathrm{H}_{2} \mathrm{O}_{2}$ was used to soak it for $30 \mathrm{mins}$ in order to kill the endogenous peroxydase and washed with distilled water 3 times. A solution of 5\% BSA confining liquid was pipetted on to the plates and stood at room temperature for 20 mins. Type I antibody (IgG2a of mice) was added to the plates, which were stood at $37^{\circ} \mathrm{C}$ for $1 \mathrm{hr}$. They were washed with PBS 3 times for 2 mins each time. The goat anti mouse $\operatorname{IgG}$, which was treated with biotin, was pipetted on to the plates. The plates were then stood at $37^{\circ} \mathrm{C}$ for $1 \mathrm{hr}$ and washed with PBS 3 times for 2 mins each time. Lastly, SABC was added and stood at $37^{\circ} \mathrm{C}$ for $1 \mathrm{hr}$, then washed with PBS 4 times for 5 mins each time. DAB was used to colour, ethanol to dehydrate; xylene to make it transparent and to make it possible to mount by neutral resin (Liu et al, 2005; Zhang et al, 2005).

\section{Results}

\subsection{The growth condition of smooth muscle cell in vitro}

New cells appeared after 6 to 7 days from the time

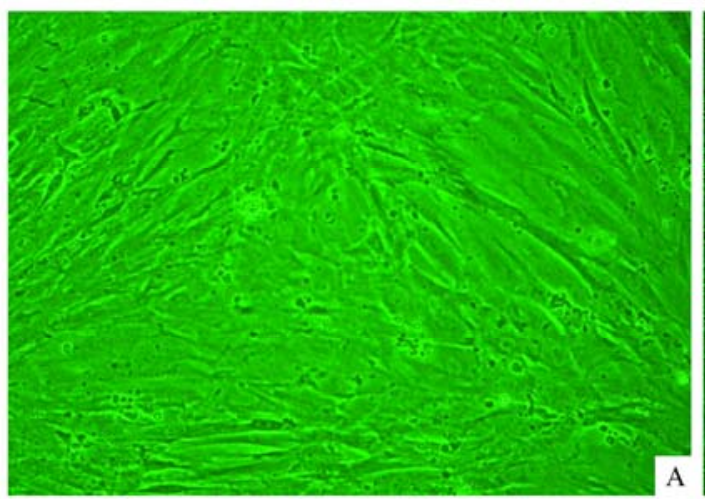

of cultivation in the incubator. Their distribution and amount were non-uniform. About 20 days later, the cells covered the bottom of the culture flask and then growed to the next generation. The second generation began after 7-9 days. The cytoplasms of cells were plentiful and the nuclei appeared elliptic or rounded; 1-3 units of dark color nucleolus could be observed. The cells were multi-morphous, showing long fusiforms or star-shaped; the apophysis of cells contacted and coalesced to each other. In some regions the cells formed multilayer that overlapped, while the other regions formed monolayer that fluctuated and are represented as a "peak- valley" shape (Fig.1A, B).

The growth curve of smooth muscle cells appear as an "S" shape. At the beginning, the amount of the cells decreased. After 2-4 days, the cells began a logarithmic growth phase. The cell growth was in plateaue phase at 7-11 days (Fig.2).

\subsection{The identification of immunohistochemistry staining}

After being treated with anti $\alpha$-SMA immunohistochemistry staining, the dyeing disc had a positive signal (the cytoplasm was brown but the nucleus could not be stained).The purity of smooth muscle cell was more than 99\%. (Fig.3).

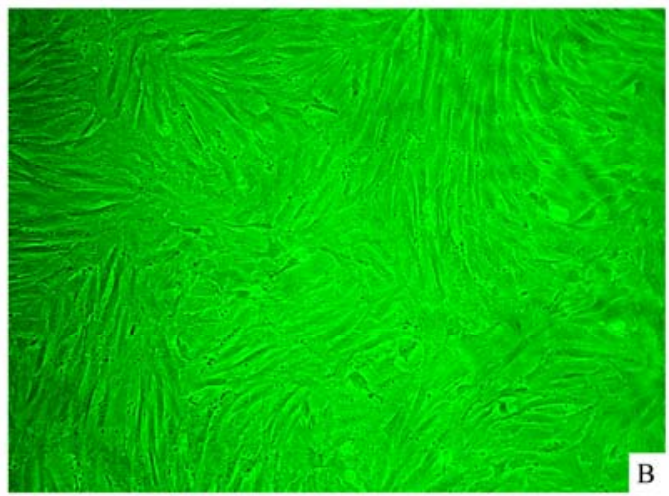

Fig. 1 The smooth muscle cells of rat ductus deferens

A. Primary cells $(\times 200)$; B. Cells of passage $1(\times 100)$.

\section{Discussion}

This experiment applied the explanting technique to cultivate the smooth muscle cells of rat ductus deferens. The advantage of this technique was that it was economical and easy to control. However, it was also susceptible to being polluted by heterocells, such as fibroblasts and endothelial cells (Jing et al, 2001; Liu et al, 2005). Therefore, it is important to eliminate the pollution of heterocells through stripping the intima and extima of the ductus deferens. Since the fast growing 


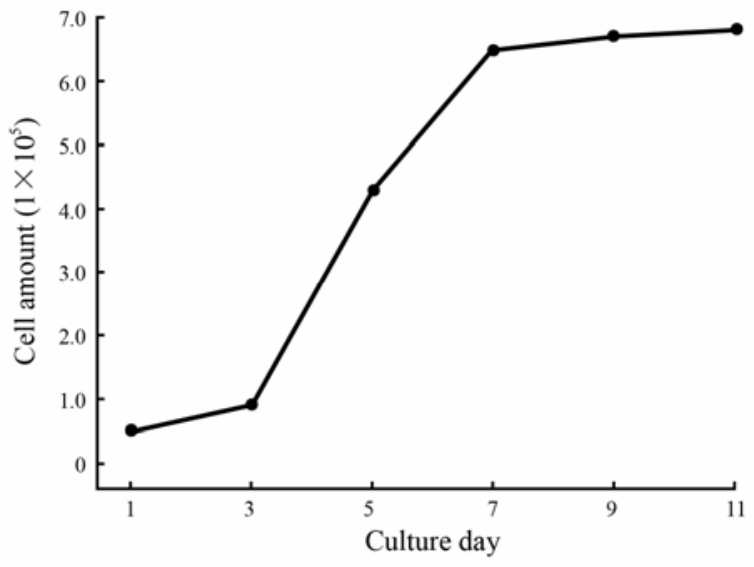

Fig. 2 Growth curve for the smooth muscle cells of the rat ductus deferens

fibroblasts were similar with the smooth muscle cells in morphology, the principle in stripping the extima was same and must be thorough. On the other hand, intima has good ductibility, the terminal of intima can be nipped to drag reversely until all the intimas were peeled away.

Thus the heterocells can be eliminated after passage of 2-3 times. The purity of the smooth muscle cells was more than $99 \%$ through identification by anti $\alpha$-SMA

\section{References:}

Huang X, Kong L, Li X, Chen X, Guo M, Zou H. 2004. Strategy for analysis and screening of bioactive compounds in traditional Chinese medicines [J]. J Chromatogr B Analyt Technol Biomed Life Sci, 812 (1-2) 71-84.

Jing T, Liu JP, He GX, Wu H, Wang HD. 2001. Use tissue adherence method to investigation of smooth muscle cells in aorta of rat $[\mathrm{J}]$. Modern Medical Journal of China, 11(9): 10-12.

LI YP, HE LC. 2007. Establishment of the model of vascular endothelial cell membrane chromatography and its preliminary application $[\mathrm{J}]$. Chinese Science Bulletin, 52: 922-928.

Liu M, Yang K, Liao KL, Zeng HC. 2005. Culture and identification of smooth muscle cells isolated from the ductus deferens of rat[J]. Journal

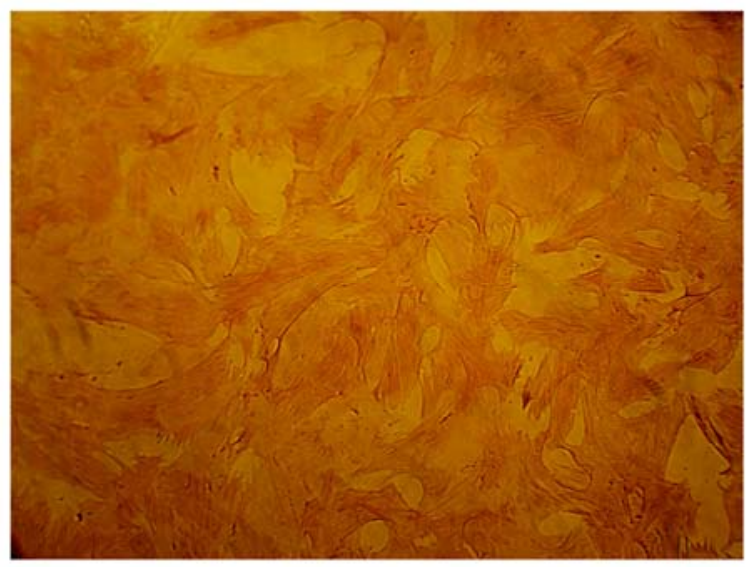

Fig. 3 The cells of anti $\alpha$-SMA immunohistochemistry staining $(\times 200)$

immunohistochemistry staining. Long culture period is another disadvantage of the tissue block method. However, when adherence occurs in the culture flask, increasing the density of tissue blocks appropriately can shorten the culture time.

In conclusion, the purity and receptor activity were much higher in the smooth muscle cells of the rat deferent duct obtained from this experiment.

of the Third Military Surgeon University, 27(12): 1297-1298.

Xu SY, Bian RQ, Chen X. 2002. Methodology of pharmacological experiment (the third edition) [M]. Beijing: People Health Publishing Company.

Yu L, Zhao J, Zhu Q, Li SP. 2007. Macrophage biospecific extraction and high performance liquid chromatography for hypothesis of immunological active components in Cordyceps sinensis[J]. Journal of Pharmaceutical and Biomedical Analysis, 44: 439-443.

Zhang JM, Huang HJ, He T. 2005. Primary culture and identification of smooth muscle cell in the corpus cavernosum of urethra of New Zealand's rabbit[J]. Surgery Journal of Chinese Experiment, 22(9): 1051-1052. 